\title{
Traditional Development of Pulse Examination as Diagnostic Tool in Ayurveda
}

\author{
Aparna Singh* \\ Department of Kriya Sharir, RLAMC, Durg - 491221, Chhattisgarh, India; appisingh23@gmail.com
}

\begin{abstract}
Nadi pariksha deals with the science of assessing the functional status of pulse for diagnosis of healthy mind, body and even soul. The presence of nadi (pulse) in an individual signifies the existence of life. Ayurveda visualizes nadi pariksha being performed to analyze and access the quantity of tridosha in body i.e. nadi provides a platform for diagnosis of normal and vitiated doshas in the body. Nadi pariksha serves as an important diagnostic tool for examination of pulse and it's importance is described in Astavidhapariksha, as one of the important diagnostic measures in ayurvedic literature. The concept of nadi pariksha was visualized in various ayurvedic texts like Sharangdhar Samhita, Yoga Ratnakar, Basavarajeeyam, Bhava Prakasha as well as in Nadi Prakasha by Ravan Samhita and Nadi vigyan by Kanad. The traditional knowledge of nadi pariksha in Ayurveda was practiced since a long time but, these documents need to be assessed as the quality of pulse described was qualitative and the same needs to be well analyzed in quantitatively for practical implication of nadi with scientific approach. This paper deals with the ancient development of diagnostic tool of examination of pulse in parlance with modern approach hence an extensive search was undertaken using key words as Nadi, Nadi pariksha etc in Google scholar, Pubmed, Google as well as ayurvedic literatures were also studied so as to re-establish facts which could be helpful in future.
\end{abstract}

Keywords: Ashtavidhapariksha, Nadi Prakash, Pulse Examination.

\section{Introduction}

Ayurveda, the traditional healthcare system of India signifies nadi pariksha as an important diagnostic tool for diagnosis of physical as well as psycological status of an individual. From time immortal, various civilizations of the world have been aware of the importance of pulse either in the form of simple means just to know the conditions of the heart or to diagnose different diseases and to access the life expectancy of patients. The traditional knowledge of pulse has been seen in various civilizations viz. Egyptian, Greek, Chinese, Arabic etc.

The significance of nadi pariksha, irrespective of the civilization has always served as a subject of great learning in the field of medicine. The Egyptian civilization (B.C 1550) is the earliest country of the world which invented the knowledge of pulse only to know the physiological condition of the heart. Galen (AD 129) one of the pioneers of Greek system of medicine has written several treaties on pulse. Avicenna (AD 980) in Greek-Arabic system of medicine nurtured his knowledge of pulse examination ${ }^{1}$.

The eminent scholars of Ayurveda visualized nadi (pulse) as the most fundamental sign of life. The early physicians paid more attention to the character of pulse in health and the changes which occurred in diseases. It served as a diagnostic tool for assessment of functional status of an individual. In today's busy life schedule as well as hectic and disturbed lifestyle, the modern physician seeks the knowledge of pulse for assessing the functional status of heart by assessing its rate,

${ }^{*}$ Author for correspondence 
rhythm, volume and character of the pulse indicate the condition of pulse.

Ayurveda possesses rich experience of nadi pariksha (pulse examination) in its classical texts but, it is emphasized on its subjective nature and it is also highly dependent on the skill of the physicians practicing since decades. Hence these ideologies need to be developed and researches should be made for developing latest scientific techniques for assessment of nadi in present scenario. The pulse examination in Ayurveda serves to analyze the physiological and functional status of tridosha in a body. The physiological concept of pulse examination in ayurveda was described in many ayurvedic literatures viz. Sharangdhar samhita, Yogaratnakar, Bhavaprakasha, Nadi Pariksha by Ravan Samhita and Nadi Vigyan by Kanad. Basavarajiyam is also one of the ancient treaties which emphasized on the diagnosis of pulse for diagnosis of disease.

Ayurveda has laid emphasis on the examination of pulse as a traditional diagnostic method of examination. Pulse examination is described as the first clinical examination in Asthasthanapariksha (eight-fold examination) ${ }^{2}$. Nadi Vigyan was also believed to be propagated in Yogashastra and Sidhasastra. It is believed that the knowledge of nadi pariksha was transferred from lord Shiva to Brahma and then subsequently to Indra and finally to Kanad. This paper deals with the ancient development of a diagnostic tool for examining the pulse in parlance with the modern approach and hence an extensive search was undertaken using key words as Nadi, Nadi pariksha etc in Google scholar, Pubmed, Google as well as ayurvedic literatures were also studied to re-establish facts which could be helpful in future.

\section{Discussion}

Nadi parikshna (assessment of pulse) serves as a diagnostic tool for diagnosis with ease and disease of an individual. It is a science of observing the pulse from the perspective of diagnosis of a healthy state of mind, body and subconsciousness. Nadi (pulse) serves as a channel which connects the body with the blood vessels and lymphatics to carry information from Srotas (organ channels), Dhatus (tissues), organs and their health and regeneration within the body.
Nadi parikshan forms the basis for evaluating the status of Tridoshas in our body. It helps to find out the vitiated doshas in a diseased condition. The term nadi pariksha can be clinically correlated with pulse examination in contemporary medical science. Nadi is also known as sphura (nerva), sira (vein), veena (strings of instrument), sphurani, hansi, dhamani (artery), jivsakshi, jivitnadnya, rasayani (lymphatic vessels), snayu (ligaments) ${ }^{3}$. These synonyms clearly indicate that pulse is basically a channel persisting within the body in the form of blood vessels.

\subsection{Ayurvedic Diagnostic Tool for Assessment of Health Status}

Ayurveda serves as a holistic approach towards assessment of health condition of an individual. For the assessment of health status of an individual, the clinical examinations in Ayurveda were described under the headings in Dasavidha pareeksha (tenfold examination), Ashtavidha pareeksha (eight-fold examination), Shadvidha pareeksha (six-fold examination), Trividha pareeksha (three-fold examination) etc. The present study lays emphasis on Ashtavidha pareeksha as the Nadi pariksha (pulse examination) was described in its first chapter under the heading "Rogi Pariksha" and also because it is the first one among the eight clinical points of assessment viz. Nadi (pulse), Mutra (urine), Mala (feces), Jihva (tongue), Shabda (sound), Sparsha (touch), Drika (vision), Aakriti (touch).

\subsection{Procedure of Pulse Examination}

The pulse assessment was done by observing the pulse with the tip of one's finger. The pulse is felt at the wrist (radial artery). The sensation of touch serves as the pathway between the patient and the examiner. This knowledge is assessed by the physician with a peaceful mind, he should examine with his right hand below the left thumb in case of females and right thumb in case of males. The expertise in attaining the knowledge of pulse is attained by regularly practicing with the pulse of an individual.

The method of examination of pulse by ayurvedic scholars serves as a very potent diagnostic measure that should be measured precisely in order to achieve correct diagnosis. The procedure of nadi pariksha indicates the 
exact location of the site of examination of pulse in karangusthamulanadi (radial artery) ${ }^{3,4}$. The process of assessment of pulse involves placing the index, middle and ring fingers on the wrist and palpating the radial artery at one finger distance from angushtamula (root of thumb). The pressure applied on the fingers indicate the presence of doshas (biological humors) by feeling the pulsation. The presence of pulsation in index finger indicates vata nadi, pulsation in middle finger indicates pittavaha nadi and the pulsation in ring finger indicates kaphavaha nadi ${ }^{5}$. The sense of pulse below the thumb detects the ease and diseased condition of an individual. While accessing the physiological function of nadi (pulse), certain points should be kept in mind for assessment which are as follows:-

1. First, the Kurpar (elbow) of the patient should be flexed to the left and wrist slightly bent to the left with the fingers distended and dispersed.

2. After attaining concentration of mind, the physician should examine the pulse in the first three hours of the morning.

3. After attaining concentration of mind, physician should examine the pulse repeatedly thrice by applying and releasing the pressure alternately.

4. By observing the pulse, the physician then decides the condition of doshas (biological humors), as to whether they are in their respective places. The condition of pulse is also assessed i.e. whether the pulse is slow, medium or fast and also whether the doshas (biological humors) are involved singly or in combination of two or all three together.

5. The presence of pulse wave enables the physician to infer whether the pulse is good or bad. Repeated practice of pulse examination makes the physician perfect in the art of its examination and in inferring the result.

6. The results of nadi pariksha (pulse examination) may be misleading when examined in certain conditions like just after bath, while hungry or thirsty or during sleep or just after waking and after exercise ${ }^{6}$.

The emphasis on the importance of pulse examination was made by comparing the sitar instrument which is made by the union of fine wires which produce music when played properly. Similarly, the pulse of the wrist if examined properly enables us to know the functional status of blood vessels. Hence, the pulse should be examined by the physician to know the physiological status of the doshas (biological humors), right from the beginning and till the end. The pulse examination also serves as specific places for gods and has allotted specific places like Vata-Brahma, Pitta for Shankar and Kapha for Vishnu, ${ }^{3,6}$.

\subsection{Assessment of Characteristics of Pulse Parameter in Ancient Literatures}

The assessment of pulse was conferred by Vaidyas (ayurvedic physician) by regular practice, by observing the pulse on the radial artery and assessing the doshas (biological humors) by palpation technique. The classical texts have emphasized qualities or properties of pulse as gati (pulse movement), vega (speed of pulse), healthy and diseased pulse with respect to stability of pulse as sthiratva (Tables 1 and 2). The qualities of pulse are visualized in qualitative manner which need to be understood in quantitative manner and hence researches should be carried out.

\subsection{Pulse in Healthy Individual and Effect of Diurnal Rhythm}

The nadi pariksha serves as an important tool for diagnosing the ease and disease of an individual. The pulse in a healthy individual is steady and strong and beats with regular intervals. The tridoshas are normal and the pulse is neither slow nor high. The pulse in a healthy individual is also affected by diurnal rhythm i.e. in morning it is snigdha (unctuous), in afternoon it is Ushna (hot), in evening it is tikshna (fast or rapid) and at night it is manda (slow). Further it is said that the pulse which beats 30 times minimum in one speed is steady and strong with all the doshas (biological humors), balanced, the pulse is neither slow nor fast in speed and remains in normal position even after pressing, it does not slow down. With all these features of pulse, a person is considered healthy ${ }^{7,9}$.

\subsection{Effect of Panchamahabhuta on Nadi - position and Speed}

The effect of Panchamahabhuta during examination of pulse was described by Acharya Harita. The 
Table 1. Properties of pulse in different doshas

\begin{tabular}{|c|c|c|c|c|c|}
\hline Properties & Vata Doshas & Pitta Doshas & $\begin{array}{l}\text { Kapha } \\
\text { Doshas }\end{array}$ & Dwandaja (two doshas) & $\begin{array}{l}\text { Sannipataja } \\
\text { (three doshas) }\end{array}$ \\
\hline 1. Varna (colour) & $\begin{array}{l}\text { Aruna } \\
\text { (reddish-brown) }\end{array}$ & $\begin{array}{l}\text { Nila } \\
\text { (blue) }\end{array}$ & $\begin{array}{l}\text { Gaura } \\
\text { (fair) }\end{array}$ & - & - \\
\hline 2. Touch (Sparsh) & Sheeta (cold) & $\begin{array}{l}\text { Ushna } \\
\text { (hot) }\end{array}$ & $\begin{array}{l}\text { Sheeta } \\
\text { (cold) }\end{array}$ & - & $\begin{array}{l}\text { Ptatiwara Bhinna } \\
\text { (Sometimes hot and } \\
\text { Sometimes cold) }\end{array}$ \\
\hline 3. Gati (velocity) & Vakra (zig-zig) & $\begin{array}{l}\text { Chapala } \\
\text { (Throbbing) }\end{array}$ & $\begin{array}{l}\text { Manda, } \\
\text { Sthira (Slow) }\end{array}$ & $\begin{array}{l}\text { VP - Vakra (zigzag), } \\
\text { VK - Vakra and Manda (slow) } \\
\text { PK - Sphuta (Jumping) } \\
\text { Manda(Slow) }\end{array}$ & Ativega (speedy) \\
\hline $\begin{array}{l}\text { 4. Niyamitta } \\
\text { (Rhythm) }\end{array}$ & $\begin{array}{l}\text { Aniyamita } \\
\text { (Irregular) }\end{array}$ & - & $\begin{array}{l}\text { Niyamita } \\
\text { (Regular) }\end{array}$ & - & Aniyamita (irregular) \\
\hline $\begin{array}{l}\text { 5. Nadi Anguli } \\
\text { Pariksha } \\
\text { (fingers used for } \\
\text { palpation) }\end{array}$ & $\begin{array}{l}\text { Tarjani (index } \\
\text { finger) }\end{array}$ & $\begin{array}{l}\text { Madhyama } \\
\text { (middle finger) }\end{array}$ & $\begin{array}{l}\text { Anamika } \\
\text { (Ring finger) }\end{array}$ & $\begin{array}{l}\text { VP - In between tarjani and } \\
\text { madhyama. } \\
\text { VK - In between anamika and } \\
\text { tarjani. } \\
\text { PK - In between madyama } \\
\text { and anamika }\end{array}$ & All three fingers \\
\hline 6. Bala (force) & $\begin{array}{l}\text { Cheena Bala (less } \\
\text { strength) }\end{array}$ & $\begin{array}{l}\text { Madyama Bala } \\
\text { (moderate } \\
\text { strength) }\end{array}$ & $\begin{array}{l}\text { Sakala } \\
\text { (strong) }\end{array}$ & $\begin{array}{l}\text { Madyama Bala (moderate } \\
\text { strength) }\end{array}$ & $\begin{array}{l}\text { Balawati } \\
\text { (strong) }\end{array}$ \\
\hline $\begin{array}{l}\text { 7. Resemblance } \\
\text { with creatures }\end{array}$ & Snake, Leech & $\begin{array}{l}\text { Sparrow, Crow } \\
\text { and frog }\end{array}$ & $\begin{array}{l}\text { Swan, } \\
\text { Pigeon }\end{array}$ & $\begin{array}{l}\text { VP - Sometimes snake and } \\
\text { Sometimes frog } \\
\text { VK - Sometimes Snake and } \\
\text { Sometimes Swan } \\
\text { PK - Sometimes Frog and } \\
\text { Sometimes Swan }\end{array}$ & $\begin{array}{l}\text { Lark, quail and } \\
\text { patridge. }\end{array}$ \\
\hline
\end{tabular}

VP - vata pitta; VK - vata kapha; PK - pitta kapha

Table 2. Characteristics of pulse in different conditions

\begin{tabular}{|c|c|c|c|}
\hline \multirow{2}{*}{$\begin{array}{l}\text { Types of pulse in } \\
\text { different condition }\end{array}$} & \multicolumn{3}{|c|}{ Characters of Pulse } \\
\hline & Sharangdhar Samhita ${ }^{7}$ & Bhava Prakasha ${ }^{8}$ & Yogaratnakar ${ }^{3}$ \\
\hline Healthy pulse & Sthira (steady) and Balawati (strong) & Sthira (steady) and Balawati (strong) & - \\
\hline Increased appetite & $\begin{array}{l}\text { Lahgwi (light to touch), Chapala } \\
\text { (tremulous), Vegawati (fast) }\end{array}$ & Chapala (tremulous) & - \\
\hline $\begin{array}{l}\text { Satisfaction after } \\
\text { hunger }\end{array}$ & Sthira (steady) & Vegavati (fast) & - \\
\hline Hungry & Vegavaha (Rapid) & - & - \\
\hline Anxiety and fear & Kshina (feeble) & Kshina (feeble) & - \\
\hline $\begin{array}{l}\text { Poor appetite and } \\
\text { cachexia }\end{array}$ & Mandatara (slow) & Manda (slow) & Manda (slow) \\
\hline Intoxication & Gurvi (heavy) & - & - \\
\hline
\end{tabular}


influence of Bhautika tatva was felt on Kanisthika finger (little finger) with the speed of pulse as Dhergha (long), Vartula (curved). The Apatatva was felt on Anamika (Ring finger) and the speed of the pulse was felt in left/right in any direction. The influence of Agnitatva was observed on Madhyama (middle) and the speed of the pulse was felt in an upward direction as the Agni (biological fire) moves up. The Vayutatva was observed in tarjini (index) and the speed of the pulse was Vakra (zigzag). The influence of Akasha tatva was observed in Angustha (Thumb) and the speed of the pulse was Shunyakara (numbness $)^{10}$.

\subsection{Pulse in a Diseased Condition in an Individual}

Nadi pariksha serves as an effective tool for diagnosis of health status of an individual since ancient times. It is the science of observing the pulse from a perspective of diagnosis of the human body, mind and subconsciousness. The expert Vaidyas in nadi pariksha have described the nature of pulse or speed of pulse in different diseases (Table 3).

Table 3. Nature of pulse in different disease conditions $^{11}$

\begin{tabular}{ll}
\multicolumn{1}{c}{ Disease Condition } & \multicolumn{1}{c}{ Character of Naadi } \\
\hline Healthy person & Stable, strong \\
Mandagni, dhaatu kshyaya & Feeble, low \\
Samavastha & Hard, tense \\
Hungry & Unstable \\
Trupta & Stable \\
Jvara & Stable \\
Vataja jvara & Curved, unstable, cold \\
Pittaja jvara & Straight, long, increased rate \\
Shlesmaja jvara & Slow, very stable, cold, \\
pichhila & Hot, irregular \\
Intake of curd rice in jvara & Mandhara (churning) \\
intake of acidic substance & Slow, vikala (irregular), fearful \\
Sexual intercourse in jvara & Similar to the movement of \\
Atisara & leech in winter \\
Amatisara & Pruthula (divided) \\
\hline
\end{tabular}

\begin{tabular}{|c|c|}
\hline Grahani & $\begin{array}{l}\text { Similar to the movement of } \\
\text { dead snake }\end{array}$ \\
\hline Arshas & $\begin{array}{l}\text { Stable, curved, slow, } \\
\text { occasionally straight }\end{array}$ \\
\hline Ajirna & Hard, \\
\hline Chhardi & $\begin{array}{l}\text { Vimarga (trespassing), } \\
\text { parusha }\end{array}$ \\
\hline Trishna & Dry \\
\hline Gulma & Trembling \\
\hline Anaha & Dridha (hard), divided \\
\hline Udavarta & Kathina (hard) \\
\hline Shoola & Persistently curved \\
\hline Amlapitta & Trembling, stout, slow \\
\hline Plihodara & Vishirna, lean, dry \\
\hline Jalodara & Full, weak, vishirna, cold \\
\hline Pandu & $\begin{array}{l}\text { Unstable, sharp, alternately } \\
\text { feeble and perceivable }\end{array}$ \\
\hline Kasa & Lean, stable, slow \\
\hline Svasa & Increased rate \\
\hline Rajayakshma & $\begin{array}{l}\text { Similar to the movement of } \\
\text { snake }\end{array}$ \\
\hline Hridroga & $\begin{array}{l}\text { Very hard, churning, lean, } \\
\text { increased rate, felt below } \\
\text { middle and small finger }\end{array}$ \\
\hline
\end{tabular}

\subsection{Effect of Age on Speed of Pulse}

As the effect of doshas were mentioned on the qualities of pulse. Similarly, the effect of age was described depicting the speed of pulse as per age. The pulse rate decreases with the advancement of age in an individual $^{12}$ (Table 4 ).

Table 4. The pulse speed at different ages

\begin{tabular}{lcc}
\multicolumn{1}{c}{ Age } & $\begin{array}{c}\text { Speed of } \\
\text { Pulse } \\
\text { (in per pal) }\end{array}$ & $\begin{array}{c}\text { Speed of Pulse } \\
\text { (per minute) }\end{array}$ \\
\hline Fetal and neonatal & 56 & 140 \\
$\begin{array}{l}\text { Less than 1 } \\
\text { year- Infant }\end{array}$ & 50 & 125 \\
Less than 3 & 40 & 100 \\
year- Child & 36 & 90 \\
From 7-14 years & 29 & 72.5 \\
From 14-20 years & 28 & 70 \\
From 21-65 years & 31 & 77.5 \\
After 65 years & & \\
\hline
\end{tabular}




\subsection{Nadi Pariksha in Contemporary Medical Sciences}

Arterial pulse is defined as the pressure change transmitted in the form of waves through arterial wall and blood column from heart to periphery. The central arterial pulse is transmitted to peripheral arteries as peripheral arterial pulse. Formation and transmission of pulse wave depends upon the elasticity of blood vessels.

The pulse recorded in radial artery or femoral artery is the typical peripheral pulse. The typical pulse tracing represents three main features anacrotic limb, catacrotic limb and catacrotic notch/ incisura ${ }^{13}$ (Table 5).

\subsection{Prior Research Work done for Illustrating Pulse Tracing}

Traditionally nadi pariksha (pulse examination) was done by observing the pulse with the help of three fingers on radial artery thereby accessing doshas from palpation of the pulse. This was done by eminent vaidyas by regular practice of pulse. This accentuated the importance of the pulse parameters in analyzing tridoshas to be a more scientific way for qualitative analysis of doshas and paved the way for researches for designing instruments for recording the pulsation of the individual.
The work by Joshi (2005) developed a computational model for recording the nadi- patterns with respect to the tridoshas in the body ${ }^{14}$. Another study by $\mathrm{Xu}$ LS et al has observed the pulse waveform changes by using a pulse sensor with a strain cantilever beam transducer ${ }^{15}$. In continuation of research a team lead by Kalange et al. used piezoelectric sensor to develop a system to detect the human pulse ${ }^{16}$. Chung-Shing $\mathrm{Hu}$, et al. has proposed pulse taking platform to obtain the pressure waveform of the wrist pulse with a single tactile sensor ${ }^{17}$.

Venkala Giri Kumar et al. studied the relevance of nadi pariksha along with recent advances in pulse wave analysis. The qualities or properties of pulse such as pulse movement (gati), speed of pulse (sthiratva) and hardness of artery (kathinya) were analyzed which play an important role in pulse examination which were also compared with the modern pulse parameters viz. pulse wave velocity, pulse rate variability and arterial stiffness with reference to pulse wave velocity in cardiovascular studies were discussed ${ }^{18}$.

\section{Conclusion}

Nadi Pariksha practiced by a skilled ayurvedic physicians from thousands of years signifies the importance of Nadi (pulse) for evaluating the health status of an individual, forecasting the susceptibility of

Table 5. Examination of pulse points in various parts of the body

\begin{tabular}{ll}
\hline \multicolumn{1}{c}{ Pulse point } & \multicolumn{1}{c}{ Area of palpation } \\
\hline $\begin{array}{l}\text { 1. Temporal pulse } \\
\text { 2. Facial pulse }\end{array}$ & $\begin{array}{l}\text { Over the temple, in front of ear on superficial temporal artery } \\
\text { On facial artery at the angle of jaw }\end{array}$ \\
3. Carotid pulse & $\begin{array}{l}\text { In the neck along anterior border of sternocleidomastoid muscle on common carotid } \\
\text { artery } \\
\text { In axilla on axillary artery }\end{array}$ \\
5. Arachial pulse & In cubital fossa along medial border of biceps muscle on brachial artery \\
6. Radial pulse & Over the thumb side of wrist between tendons of brachioradialis and flexor carpi \\
7. Ulnar pulse & radialis \\
8. Femoral pulse & Over the little finger side of wrist on ulnar artery \\
9. Popliteal pulse & In the groin on femoral artery \\
10. Dorsalis pedis pulse & Behind knee, in the popliteal fossa on popliteal artery. \\
11. Tibial pulse & Over the dorsum of foot on dorsalis pedis artery. \\
\hline
\end{tabular}


the disease, for disease diagnosis and prognosis of the disease. Ayurvedic literature serves as an extensive field of knowledge regarding the examination of the pulse and it is considered as one of the important factors in eight-fold examination as it is described as the first and foremost point of clinical examination by Yogaratnakar. The eminent masters of Ayurveda have described the parameters of nadi pariksha viz. rate, rhythm, character etc. which need to be studied in parlance with contemporary medical sciences to put forward the hidden secrets of nadi pariksha. Hence there is an extensive need of research to be done for development of pulse examination techniques and instruments should be designed to standardize the assessment of nadi pariksha in a scientific way for diagnostic purpose.

\section{References}

1. Upadhyaya S. Nadi Vigyan. Reprinted. Delhi: Chaukambha Sanskrit Pratisthan; 2005. p. 3.

2. Shastri L. Yogaratnakar of Yogratnakara with Vidyotini hindi commentary. Reprinted. Varanasi: Chaukambha Prakashan; 2007. p. 5.

3. Shastri L. Yogaratnakar of Yogratnakara with Vidyotini hindi commentary. Reprint edition. Varanasi: Chaukambha Prakashan; 2007. p. 6.

4. Srivastava S. Sharangdhar Samhita of Sharangdhara. Reprint edition. Varanasi: Chaukambha Orientalia; 2009. p. 24.

5. Upadhyaya S. Nadi Vigyan. Reprinted. Delhi: Chaukambha Sanskrit Pratisthan; 2005. p. 63.

6. Shastri L. Yogaratnakar of Yogratnakara with Vidyotini hindi commentary. Reprint edition. Varanasi: Chaukambha Prakashan; 2007. p. 5.

7. Srivastava S. Sharangdhar Samhita of Sharangdhara. Reprint edition. Varanasi: Chaukambha Orientalia; 2009. p. 26
8. Sitaram B. Bhavaprakash of Bhavamishra. Reprint edition. Varanasi: Chaukambha Orientalia; 2015. p. 668-69.

9. Shastri L. Yogaratnakar of Yogaratnakar with Vidyoti. Reprint edition. Varanasi: Chaukambha Prakashan; 2007.p. 9

10. Dadhich NK, Sharma P. A comprehensive knowledge on Nadi Pariksha. American Journal of Research in Medical Sciences. 2016; 1(2):190-5.

11. Upadhyaya GP. Ayurvediya Nadi Pareeksha Vigyana. Varanasi; Chaukambha Surabharati Prakashana; 2009. p. 91.

12. Upadhyaya GP. Ayurvediya Nadi Pareeksha Vigyana. Varanasi; Chaukambha Surabharati Prakashana; 2009. p. 21

13. Sembulingam $K$ and Sembulingam P. Essentials of Medical Physiology. Reprint edition. New Delhi: Jaypee Brothers Medical Publishers (P) Ltd; 2012. p. 623-27. https://doi. org/10.5005/jp/books/11696_42

14. Joshi RR. Diagnostics using computational Nadi patterns. Mathematical and Computer Modeling. 2005; 41(I):33-47. https://doi.org/10.1016/j.mcm.2004.05.002

15. Xu LS, Wang KQ, Wang L, Maimin Li. Pulse contour variability before and after exercise. 19th IEEE International Symposium on Computer-Based Medical Systems (CBMS); 2006. p. 237-40. https://doi.org/10.1109/CBMS.2006.136

16. Kalange A, Gangal S. Piezoelectric Sensor for Human Pulse Detection. Defence Science Journal. 2007: 57(1):109-14. https://doi.org/10.14429/dsj.57.1737

17. Chung-Shing $\mathrm{Hu}$, Yu-Feng Chung, Cheng-Chang Yeh, Ching-Hsing Luo. Temporal and spatial properties of arterial pulsation measurement using pressure sensor array. Evidencebased Complementary and Alternative Medicine. 2012: 9. https://doi.org/10.1155/2012/745127. PMid:21754947. PMCid:PMC3132467

18. Kumar PVG, Deshpande S, Nagendra HR. Traditional practices and recent advances in Nadi Pariksha: A comprehensive review. Journal of Ayurveda and Integrative Medicine. 2018 Aug 10; In press. https://doi.org/10.1016/j. jaim.2017.10.007. PMCid:PMC6598790 